\title{
Development of Solar Powered Buggy Charging Station
}

\author{
Hamzah Sakidin 1, *, Mohd Faizairi M. Nor ${ }^{2}$, Suhaimi Hassan $^{2}$, Firdaus Basrawi ${ }^{3}$, Asmala \\ $\mathrm{Ahmad}^{4}$, Imran Rahman ${ }^{1}$ \\ ${ }^{1}$ Department of Fundamental \& Applied Sciences, Universiti Teknologi PETRONAS, 32610 Bandar \\ Seri Iskandar, Perak, Malaysia. \\ ${ }^{2}$ Department of Mechanical Engineering, Universiti Teknologi PETRONAS, 32610 Bandar Seri \\ Iskandar, Perak, Malaysia. \\ ${ }^{3}$ Faculty of Mechanical Engineering, Universiti Malaysia Pahang, 26600 Pekan, Kuantan Pahang, \\ Malaysia. \\ ${ }^{4}$ Faculty of Information Technology \& Communication, Universiti Teknikal Malaysia Melaka, Hang \\ Tuah Jaya 76100 Durian Tunggal, Melaka Malaysia.
}

\begin{abstract}
The renewable energy became an essential demand for today's world life for all its importance in decreasing pollution and keeping our environment clean. The solar car is a step in saving our environment and energy resources. The New project under Universiti Teknologi PETRONAS (UTP) - URIF grant is targeted to run the university Buggy using solar photovoltaic. The 48V Buggy Car Charging Station has been developed and installed at Property Management and Maintenance Office (PMMO), UTP. A new solar-powered buggy car is assembled in innovative manner with state-of-art material and component. The maximum solar voltage allowed for the system is $150 \mathrm{~V}$ at $45 \mathrm{Acharging}$ rate and the maximum efficiency of MPPT/CHARGER could be as high as $98 \%$.
\end{abstract}

\section{Introduction}

In places like universities and large companies, the utilization of buggy car is gaining wide popularity. The traditional gasoline power-driven buggy cars are less effective and create very harmful emissions to the surroundings [1-2]. On the other hand, Electric golf carts are relatively efficient and friendly to environment. However, its do not have a long driving range and their on-board batteries require to be regularly recharged. Universiti Teknologi PETRONAS (UTP) has two buggy cars managed by the Property Management and Maintenance Office (PMMO). These buggy cars are generally parked near PMMO parking area during the daytime while the maintenance staff carries out their routine responsibilities.

Due to the location, the parking roof always receives a substantial amount of daylight throughout the year and the solar energy can be harnessed by photovoltaic PV panels to uninterruptedly recharge the buggy cars' battery. Malaysia is located at the equatorial region with an average solar radiation of $400-600 \mathrm{MJ} / \mathrm{m}^{2}$ per month [3]. It has a promising potential to establish large scale solar power installations [4]. Installing a PV panel on an electric buggy

\footnotetext{
*Corresponding author: hamzah.sakidin@utp.edu.my
} 
car has several significant benefits, such as, 1) generating significant savings in electrical energy required to recharge the batteries of buggy cars [5],2) enhancing the driving range of the car by a significant amount [6] 3) Increasing the life of the batteries by avoiding deep discharging, and 4) Sponsoring sustainability awareness on campus.

Taking advantage of the sustainability initiative on campus, "UTP SOLAR PARKING (USP)", Project had undertaken the task to use PV panel in order to recharge the batteries of two buggy cars. In this paper, the design, initial system set-up and analysis are presented including future directions.

\section{Design Concept}

In order to design the buggy car charging station it is important to define the main steps. The System design main steps are:

1. Determine the power consumption of each buggy car

2. Sizing the PV Modules

3. Sizing the DC charge controller

4. Sizing the batteries.

The concept of buggy car charging station based on PV solar panels are shown in the Figure 1.

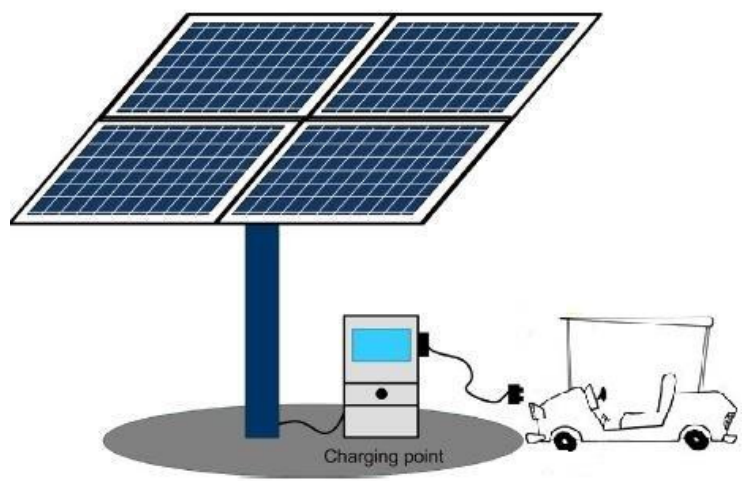

Fig. 1. The Concept of Buggy Car Charging Station Based on PV Solar Panels.

The charging station was built in order to facilitate the university to move forward towards sustainable green campus [7]. The two buggy cars are frequently use for the movement of guests and delegates coming to UTP campus for meeting, seminar or investigation purpose.

Therefore, it is a part of university prestige in front of honourable figures. Shifting towards solar energy source from conventional power grid source surely make the image of UTP brighter in front of the guests. The design concept was carefully handled by the experienced researchers from UTP with the help of engineering students.

\section{System Setup and Configuration}

The total system of solar parking has designed in order to get maximum utilisation of solar energy [8]. For this wake, the controller identify the battery voltage automatically. In this case, the system is rated at 48V. Firstly, it is required to connect the buggy car battery first to the charger by turning $\mathrm{ON}$ the contactor $\mathrm{S} 1$. The system submenu for the charger will then display some parameters like battery voltage, temperature, State-of-Charge (SoC) and so on. 
After that, the stored battery (as input voltage) is connected ( $60 \mathrm{~V} \times 5$ batteries in series) to the charger by turning ON the contactor MCB 2 .

The system submenu must be able to display the charging current (I-chg), charging power (P-chg) and charging capacity (E-chg). To display the system status for storage battery, it is necessary to connect those batteries to the MPPT controller. This is done by turning ON the contactor MCB 1. Now the system sub-menu will display the status of the storage system like battery voltage, temperature, SoC and load status. Finally to charge the storage battery using solar panels, S1 should be turn ON (optional) to connect between solar panels output to the input of MPPT controller.

Full charge is very important for the battery and should be full charged at least once a month or the battery will suffer permanent damage. The maximum solar voltage allowed for the system is $150 \mathrm{~V}$ at $45 \mathrm{~A}$ charging rate and the maximum efficiency of MPPT/Charger could be as high as $98 \%$. Figure 2 shows the schematic diagram of buggy car charging station.

The buggy car is driven by a 48V, $3.2 \mathrm{HP}$ DC motor fed by 4 deep cycle, $12 \mathrm{~V}$ lead acid batteries. The PV panel was connected to the batteries via a Maximum Power Point Tracking (MPPT) charge controller. It is an advanced charging technique to detect the real-time power of the solar panel and the maximum point of I-V curve which make the highest battery charging efficiency. Generally, the MPPT controller's energy utilization efficiency is $15 \%$ $20 \%$ higher than normal PWM controller [9].

MPPT controller will adjust the parameters (surrounding temperature and sunshine condition) constantly according to different conditions to make the system working in the largest point. Figure 3 shows the MPPT charging controller.

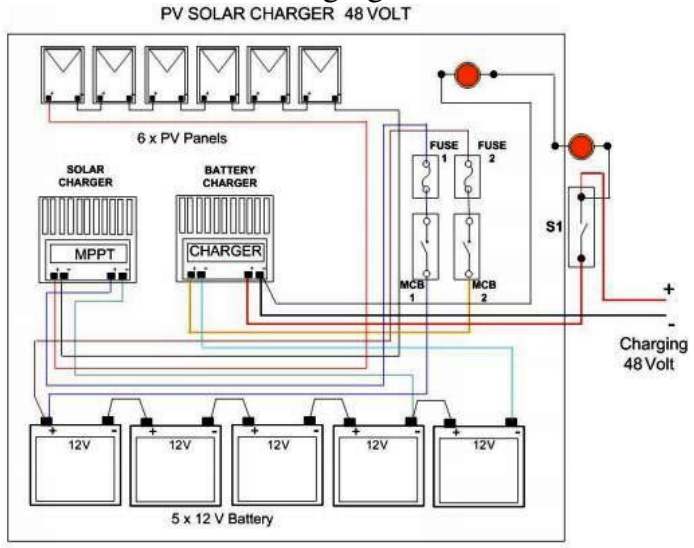

Fig. 2. Schematic of 48V Buggy Car Charging Station Based on PV Solar Panels Using MPPT Charger Controller.

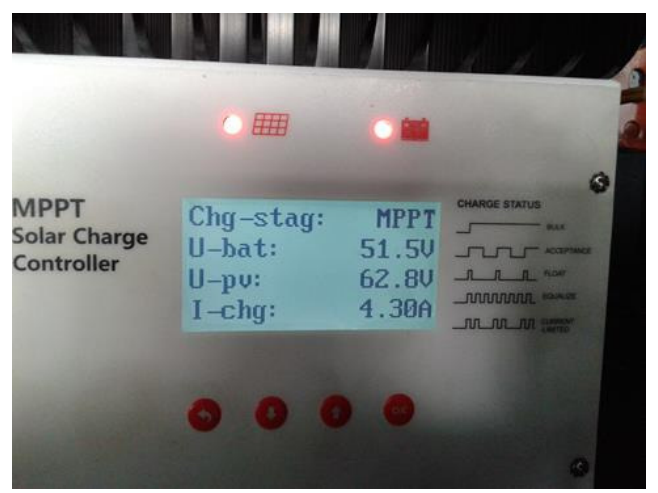

Fig. 3. MPPT Solar Charge Controller. 
MPPT charging modes include boost charging, float charging and equalizing charging. The MPPT will identify the battery voltage at first, if the voltage exceeds $52.8 \mathrm{~V}$ (for $48 \mathrm{~V}$ system) or $13.2 \mathrm{~V}$ (for $12 \mathrm{~V}$ system), it will enter float charging directly without equalizing charging or boost charging. If the battery voltage is lower than $52.8 \mathrm{~V}$ (for $48 \mathrm{~V}$ system) or $13.2 \mathrm{~V}$ (for $12 \mathrm{~V}$ system), the charging process will flow as [10]:

\section{MPPT (equalizing charging) $>$ Boost Charging $>$ Float Charging}

The equalizing charging time is $1 \mathrm{~h}$, boost charging time is $2 \mathrm{~h}$, and equalizing charging interval is 30 days. With current-limiting charging mode, when the power of solar panel is over-sized and charging current exceeds the rated current, the controller will lower the charging power, which enables the system to work under the rated charging current. The menu to examine the system status and the detail displaying status items are shown in Table 1.

Table 1. Parameters.

\begin{tabular}{|l|l|}
\hline Name & LCD display \\
\hline Charging stage & Chg-stag: \\
\hline Battery voltage & U-bat: \\
\hline Solar panel voltage & U-pv: \\
\hline Charging current & I-chg: \\
\hline Load status & Load: \\
\hline Discharging current & I-load: \\
\hline Battery capacity (SoC) & SoC: \\
\hline Charging power & P-chg: \\
\hline Discharging power & P-load: \\
\hline The max voltage & Vmax: \\
\hline The min voltage & Vmin: \\
\hline Charging capacity (AH) & C-chg: \\
\hline Discharging capacity (AH) & C-load: \\
\hline Charging capacity (WH) & E-chg: \\
\hline Discharging capacity (WH) & E-load: \\
\hline Running days & Rundays: \\
\hline Over-discharge times & LVD-CNT: \\
\hline Full charge times & FUL- CNT: \\
\hline Fault code & Fault: \\
\hline
\end{tabular}

The submenu of the system can check the current running parameters such as battery voltage, charge-discharge current, and fault code and so on, thus good for system maintenance.

The menu to set the system running parameters and the detail parameters for $48 \mathrm{~V}$ system are shown in Table 2.

Table 2. System configuration.

\begin{tabular}{|l|l|}
\hline Name & LCD display \\
\hline Over voltage discharge & OVD: \\
\hline Charging limited voltage & CLV: \\
\hline Equalizing charge voltage & ECV: \\
\hline Boost return voltage & BCV: \\
\hline Float charge voltage & FCV: \\
\hline Boost return voltage & BCV-R: \\
\hline Low voltage reconnect & LVR: \\
\hline Under voltage warning & UVW: \\
\hline
\end{tabular}




\begin{tabular}{|l|l|}
\hline Low voltage disconnect & LDV: \\
\hline Equalizing charge duration & EQV-T: \\
\hline Boost charge duration & BST-T: \\
\hline Equalizing charge interval & EQV-Inv: \\
\hline $\begin{array}{l}\text { Temperature compensation } \\
\text { coefficient }\end{array}$ & TEMP-Com: \\
\hline Load mode & L-Mode: \\
\hline Light control voltage & L-CON-V \\
\hline Controller address & Address: \\
\hline
\end{tabular}

The configurable items and configuring range of system configuration submenu must be operated cautiously, when setting the parameters to insure the proper operation of the system. There need some protective measurement for the system to run smoothly such as [11-13]:

- Waterproof degree:

IP32

- Input power limit protection:

When the PV power exceeds the rated power, controller will limit the PV power under the value of rated power so as to prevent the controller from being damaged, the controller will charge by limited current.

- Battery reverse connection protection:

Battery reverse connection will not damage the controller but the system will stop working.

- The voltage of PV input terminal is over value:

When the voltage of PV input terminal is over value, controller will shut the PV input automatically.

- Short circuit protection of PV input terminal:

Load short circuit will not damage the controller but controller will stop output.

- Reverse charge protection at night:

Prevent the battery from discharge at night.

- TVS lightning protection

- Over temperature protection

It is widely accepted that efficiency of photovoltaic solar cells decreases with an increase of temperature, and cooling is important at high illumination conditions such as concentrated sunlight, or cosmic or tropical conditions [14]. When inside temperature of the controller is over value, the controller will lower charging power or stop charging [15].

The total system was built only to charge two buggies in order to make the overall efficiency higher. The parking rooftop was used in order to place the six PV panels. The night time charging facility is also arranged whereas the buggies are used throughout the day. The batteries of charging station store charge from solar power during daytime hence power the buggies during night. Figure 4 shows the overall scenarios of buggy car charging system. Starting from $6 \mathrm{PV}$ panels on rooftop, charging station then MPPT charging controller, Buggy car batteries (48 V) along with Cable plugged-in for charging the two buggy cars. 


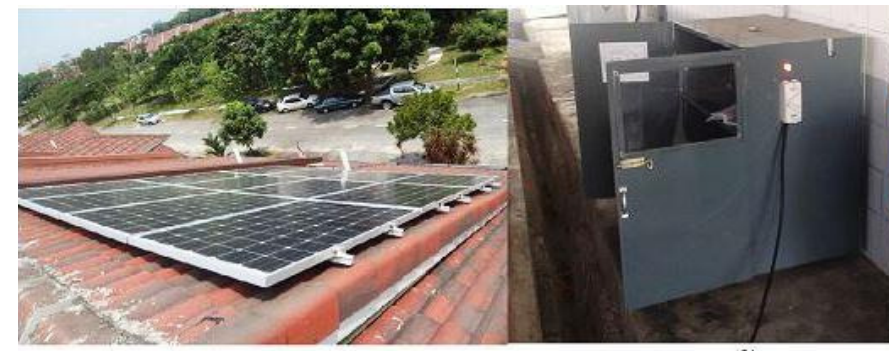

(a)

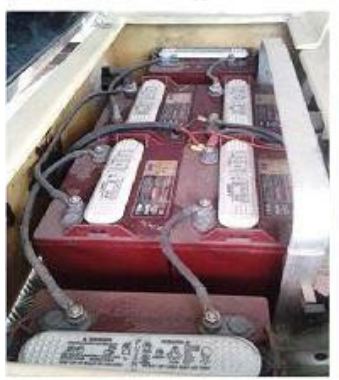

(d)

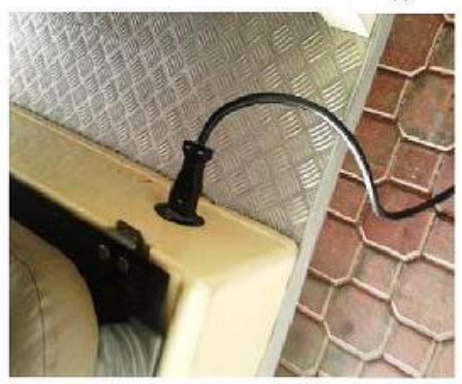

(e)

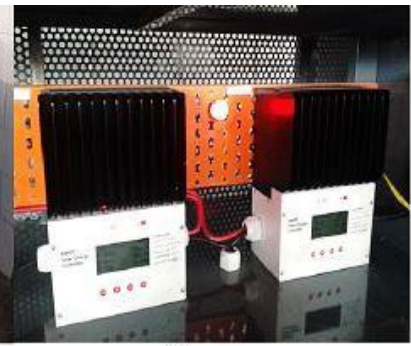

(c)

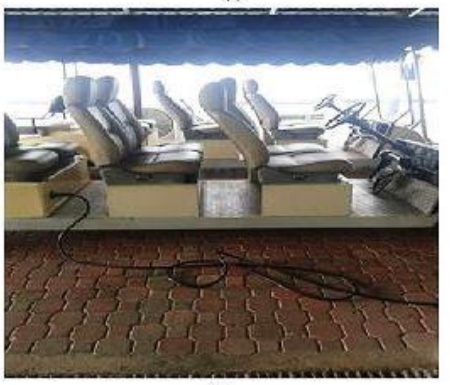

(f)

Fig. 4. 48V Buggy Car Charging Station at PMMO, UTP (a) 6 PV panels on rooftop, (b) Charging station, (c) MPPT charging controller (d) Buggy car batteries (48 V), (e) Cable plugged-in for charging, (f) The two buggy cars.

\section{Future Research Directions}

As we all know that, renewable energy became an essential demand for today's world life for all its importance in decreasing pollution and keeping our environment clean. However, it's important to shift our energy usage into renewable and clean one. This conversion has significant positive economic and environmental effects. In this paper, the utilization of solar power in buggy cars application was implemented. The alternative selection of the appropriate components for this application will be studied further along with detailed analysis in order to achieve the environmental sustainability. Hence, it will be very effective for the future generation who keen towards the adoption of green technology. However, more advanced solar PV cell should be introduced in near future in order to charge the buggies more efficiently.

\section{Conclusion}

As petrol price is rising day after day to a distinguished limit, acquiring a fuel vehicle become costly for everyone, meanwhile the vehicles using gasoline fuel is contributing by a high percentage in environment pollution and a bad effect on the global warming. Most of vehicles' manufacturers are doing their best for producing vehicles which can use different renewable energy sources. In this direction, we have done a contribution by achieving a solar buggy car charging station.

This research was funded by University Research Internal Fund (URIF) Project entitled "UTP SOLAR PARKING (USP)", Project Cost Centre No. 0153AA-B42. 


\section{References}

1. A. H.Osman, \& M. M. Massoud, European Scientific Journal, 61-67 (2013)

2. J. Kim, D. Baek, J. Hong, \& N. Chang, 2014 IEEE 57th International Midwest Symposium on Circuits and Systems (MWSCAS), (2014)

3. S. Mekhilef, A. Safari, W. E. S. Mustaffa, R. Saidur, R.Omar, M. A. A Younis, Renew Sust Energ Rev, 16(1), 386-396 (2012)

4. I. Rahman, P.M. Vasant, B.S.M. Singh, M. Abdullah- Al-Wadud, N. Adnan, Renew Sust Energ Rev, 58 (2), 1039-1047 (2016)

5. B. Guha, R. J. Haddad, Y. Kalaani In SoutheastCon 2015 IEEE (2015)

6. S. S. Yahya, A. R. M. Ariffin, M. A. Ismail, Journal of Building Performance, 5(1), 62$73(2014)$

7. Z. Wadud, L. Aye, T. Beer, H.C. Watson, J. Civ. Eng, 34, 115-127 (2006)

8. J. Torres, R. Gonzalez, A. Gimenez, J. Lopez, Applied Energy, 113, 816-824 (2014)

9. M. Rawson, S. Kateley, SAE Technical Paper (California Energy Commission, 1998)

10. M. Yilmaz, P. Krein, IEEE Trans Power Elec., 28, 2151-2169 (2013)

11. W. Su, H. Eichi, W. Zeng, M.-Y. Chow, IEEE Trans Industrial Informatics, 8, 1-10 (2012)

12. W. Su, J. Wang, Z. Hu, Plug In Electric Vehicles in Smart Grids, 61-98 (2015)

13. P. Richardson, D. Flynn, A. Keane, IEEE Trans Power Syst, 27, 268-279 (2012)

14. Z. Luo, Z. Hu, Y. Song, Z. Xu, H. Lu, IEEE Trans Power Syst, 28, 3546-3555 (2013)

15. E. Sortomme, M.M. Hindi, S.J. MacPherson, S. Venkata, IEEE Trans Smart Grid, 2, 198-205 (2011) 